\title{
Oxidation and Degradation of a Plasma-Sprayed Thermal Barrier Coating System
}

\author{
J. Allen Haynes, E. Douglas Rigney \\ Department of Materials and Mechanical Engineering \\ University of Alabama at Birmingham \\ Birmingham, AL 35294 \\ Mattison K. Ferber, Wallace D. Porter \\ High Temperature Materials Laboratory \\ Oak Ridge National Laboratory \\ Oak Ridge, TN 37831-6069

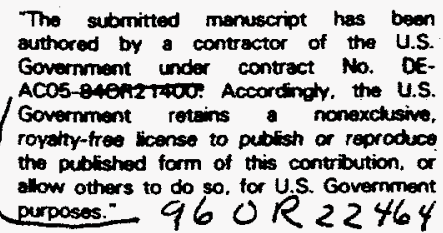

\section{ABSTRACT}

The isothermal oxidation behavior of thermal barrier coating (TBC) specimens consisting of single-crystal superalloy substrates, vacuum plasma-sprayed $\mathrm{Ni}-22 \mathrm{Cr}-10 \mathrm{Al}-1 \mathrm{Y}$ bond coatings and air plasma-sprayed $7.5 \mathrm{wt} \%$ yttria stabilized zirconia top coatings was evaluated by thermogravimetric analysis at $1150^{\circ} \mathrm{C}$ for up to 200 hours. Coating durability was assessed by furnace cycling at $1150^{\circ} \mathrm{C}$. Coatings and reaction products were identified by $\mathrm{x}$-ray diffraction, field-emission scanning electron microscopy and energy dispersive spectroscopy.

\section{MASTER}




\section{DISCLAIMER}

Portions of this document may be illegible in electronic image products. Images are produced from the best available original document. 


\section{Introduction}

Thermal barrier coatings (TBCs) are applied to gas turbine engine blades and vanes in order to reduce their operating temperatures, thus increasing component durability. A typical duplex TBC system consists of a thermally insulating ceramic top coating applied over an oxidation-resistant metallic bond coating. The most common top coating is air plasma-sprayed (APS) yttria stabilized zirconia (YSZ). Plasma-sprayed YSZ provides a porous ceramic layer possessing good strain tolerance and low thermal conductivity. Bond coatings typically consist of an $\mathrm{MCrAlY}(\mathrm{M}=\mathrm{Ni}$, and/or Co) alloy applied by either APS or vacuum plasma spraying. The bond coat provides a rough surface to which the APS YSZ can mechanically bond, and protects the substrate from oxidation by forming a continuous scale at the bond coat/YSZ interface through the selective oxidation of aluminum [1].

It is generally agreed that cyclic thermal expansion mismatch strains and growth of the interfacial oxide scale are the dominant TBC degradation mechanisms leading to failure by spallation of the YSZ top coat $[2,3,4]$. However, the specific role of oxidation in the TBC damage accumulation process is not well understood [5]. Formation and growth of the interfacial scale involves a number of high-temperature solid-state reactions occurring in a complex multielement environment. An increased understanding of bond coat oxidation behavior and its effect(s) on YSZ degradation should provide valuable insight into methods of improving coating durability and TBC life prediction capabilities. The objective of this study was to evaluate the isothermal and cyclic oxidation behavior of a typical plasma-sprayed TBC system at an elevated temperature which accelerated the oxidation process. Subsequent phases of this study will use these methods to evaluate TBCs applied by electron beam-physical vapor deposition. 


\section{Experimental}

\subsection{Materials}

Superalloy substrate discs $(2.2 \mathrm{~cm}$ diameter by $0.3175 \mathrm{~cm}$ thick with $0.08 \mathrm{~cm}$ edge radii) were machined from single-crystal slabs of Rene'N5 (composition listed in Table I). Substrate surfaces were grit-blasted, cleaned and vacuum plasma-sprayed (VPS) with $\mathrm{Ni}-22 \mathrm{Cr}-10 \mathrm{Al}-1 \mathrm{Y}(\mathrm{wt} . \%)$ bond coatings to a nominal thickness of $150 \mu \mathrm{m}$. Atomized spherical powders of $-45 /+10 \mu \mathrm{m}$ size (Praxair NI-343) were used for the first $100 \mu \mathrm{m}$ of bond coat, and powders of $-106 /+53 \mu \mathrm{m}$ size (Praxair NI-211) were used for the outer $50 \mu \mathrm{m}$ in order to provide adequate roughness for top coat mechanical adhesion.

Top coatings were applied by air plasma-spraying (APS) 7.5 wt.\% YSZ (with 1.5 wt.\% hafnia) to a thickness of either 250 or $500 \mu \mathrm{m}$. The spherical YSZ powders were $-106 /+10 \mu \mathrm{m}$ size (Metco 204NS). Table II lists APS and VPS parameters.

\subsection{Isothermal Oxidation}

Four types of specimens (described in Table III) were prepared for thermogravimetric analysis (TGA). Type B, C and D specimens were coated on both faces. Substrate edges were not directly coated, but were covered by overspray.

Isothermal oxidation weight gains were measured by continuous thermogravimetry using an ATI/Cahn TG-171 high-mass TGA system with a vertical tube furnace configuration. Tests were conducted at $1150^{\circ} \mathrm{C}\left( \pm 3^{\circ} \mathrm{C}\right)$ in dry air flowing at $100 \mathrm{~cm}^{3} \mathrm{~min}^{-1}$. Specimens were suspended from a sapphire hanger in a Pt - Rh wire basket. They were heated in the reaction gas at a rate of $50^{\circ} \mathrm{C} / \mathrm{min}$, isothermally held for $1,50,100$ or 200 hours, and cooled to room temperature at an average rate of $8.0^{\circ} \mathrm{C} / \mathrm{min}$. 


\subsection{Thermal Cycling}

Thermal cycle testing was conducted in a programmable, automated furnace at $1150^{\circ} \mathrm{C}$. Specimens were coated on one face with a $250 \mu \mathrm{m}$ TBC. Thermal cycles consisted of a 15 minute heat up to $1150^{\circ} \mathrm{C}\left( \pm 5^{\circ} \mathrm{C}\right)$, a 60 minute isothermal hold at $1150^{\circ} \mathrm{C}$ in static ambient air, and forced air cooling for 30 minutes to approximately $90^{\circ} \mathrm{C}$. Specimens were examined at 12 cycle intervals until failure (defined by visible cracking or delamination of the YSZ) occurred.

\subsection{Characterization}

Oxides which formed on the bare metal surfaces during isothermal oxidation were identified by $\mathrm{X}$-ray diffraction (XRD). Oxide morphologies and compositions were evaluated by field-emission SEM/EDS of NiCrAlY surfaces and metallographically prepared cross-sections of TBC-coated specimens (after 1, 100 and 200 hours).

\section{Results and Discussion}

\subsection{Isothermal Oxidation}

The isothermal oxidation curves for the 4 types of TGA specimens at $1150^{\circ} \mathrm{C}$ are compared as parabolic plots (specific weight gain vs. square root of time) in Figs. 1(a) - 1(d). After an initial transient period defined by rapid weight gains (partially due to growth of non-protective oxides with rapid growth kinetics) the steady state oxidation kinetics of the coated specimens decreased to near-parabolic rates (indicating predominately diffusion controlled growth of a continuous, protective scale). Although slight reductions in NiCrAlY oxidation kinetics have been reported as a function of YSZ presence $[4,6]$, such an effect was not apparent in this study. If such an effect existed, then it may have been masked by NiCrAlY surface area variations. 
In order to illustrate the effects of NiCrAIY surface roughness (which is illustrated in the TBC cross-section of Fig. 2a) on the magnitude of the measured weight gains, the surface area of a bare substrate (with a planar surface) was used to calculate all specific weights in Figs. 1(a) - 1(d). A bond coat surface area correction factor was estimated by polishing the surfaces of specimen B-4 (bare $\mathrm{NiCrAlY}$ ) to $3.0 \mu \mathrm{m}$ alumina and comparing its oxidation rate to the average rate of the other Type B specimens. It was estimated that the average surface areas of the rough bond coatings were 2.4 times greater than that of the polished specimen, with the estimation valid only in the steadystate region. The initial effective surface area difference was likely much greater (as evidenced by comparison of the magnitudes of the transient weight gains in Fig. 1b) due to particle undercuts and micropores on the as-sprayed NiCrAlY surfaces. These small scale surface defects are closed by scale growth during the transient stage of oxidation, greatly reducing the effective surface area over which steady-state oxidation occurs.

Parabolic oxidation rate constants, $k_{p}$, were estimated from the steady-state portions of the weight gain curves after correction for surface roughness, buoyancy and Pt basket evaporation effects. The oxidation rate constant is generally defined by the equation $\Delta W / A=k_{p}{ }^{1 / 2} t^{1 / 2}$, where $\Delta W$ is the weight change at any time $t$, and $A$ is the surface area of the specimen. The weight gains, test conditions, and estimated $k_{p}$ values are listed for each specimen in Table $\mathrm{IV}$. The general trend of decreasing oxidation rate with increasing exposure time may be another indication of the decreasing effective surface areas of the bond coatings.

The $k_{p}$ value of specimen B-4 (polished) was calculated to be $1.51 \times 10^{-12} \mathrm{~g}^{2} \mathrm{~cm}^{-4} \mathrm{~s}^{-1}$ which is on the order of the value reported for an alumina-forming $\mathrm{Ni}-20 \mathrm{Cr}-13 \mathrm{Al}-0.07 \mathrm{Zr}$ alloy $\left(\mathrm{k}_{\mathrm{p}}=5.2 \mathrm{x}\right.$ $10^{-13} \mathrm{~g}^{2} \mathrm{~cm}^{-4} \mathrm{~s}^{-1}$ ) at $1150^{\circ} \mathrm{C}[7]$. The mean $k_{p}$ value of all TBC-coated specimens was $1.3 \times 10^{-12} \mathrm{~g}^{2}$ $\mathrm{cm}^{-4} \mathrm{~s}^{-1}$, which was lower than the value reported at $1083^{\circ} \mathrm{C}$ in oxygen $\left(k_{p}=3.9 \times 10^{-12} \mathrm{~g}^{2} \mathrm{~cm}^{-4} \mathrm{~s}^{-1}\right)$ for $\mathrm{Ni}-18 \mathrm{Cr}-12 \mathrm{Al}-0.3 \mathrm{Y}$ coated with APS YSZ [6].

No spallation of YSZ occurred during or after isothermal testing up to 200 hours. Slight spallation of the scales on the bare NiCrAlY was noted during cooling. 


\subsection{Superalloy and Bare NiCrAlY Reaction Products}

$\mathrm{X}$-ray diffraction of the as-sprayed $\mathrm{NiCrAlY}$ detected $\gamma^{\prime}\left(\mathrm{Ni}_{3} \mathrm{Al}\right)$ and $\beta$ (NiAl) as the major phases. The primary phases of as-sprayed VPS Ni-22Cr-10Al-1Y (as determined by electrolytic extraction) have been reported as $\gamma$ (nickel solid-solution), $\gamma^{\prime}, \beta, \alpha-\mathrm{Cr}$ and $\mathrm{Y}_{2} \mathrm{O}_{3}[8]$.

After oxidation for one hour, XRD of the bare NiCrAlY surfaces detected $\alpha-\mathrm{Al}_{2} \mathrm{O}_{3}, \mathrm{NiAl}_{2} \mathrm{O}_{4}$ (spinel), and $\mathrm{Y}_{2} \mathrm{O}_{3}$ as reaction products. After 50,100 and 200 hours, $\alpha-\mathrm{Al}_{2} \mathrm{O}_{3}$ was the major oxide phase on the bare NiCrAlY, with lesser amounts of $\mathrm{NiAl}_{2} \mathrm{O}_{4}$ and $\mathrm{Al}_{5} \mathrm{Y}_{3} \mathrm{O}_{12}$ (yttria-alumina garnet or YAG). The $\mathrm{Y}_{2} \mathrm{O}_{3}$ which was detected in the scale after 1 hour oxidation likely converted to $\mathrm{YAG}$ by reaction with $\mathrm{Al}_{2} \mathrm{O}_{3}$ at the longer test periods. Small isolated pockets of NiO were detected on the scale surface by SEM/EDS after 200 hours oxidation. As shown in Fig. 2(b), localized cracking and partial spallation of the scale from the spherical NiCrAlY surface particles was common (after 100 or 200 hours isothermal oxidation), but the scale remained adherent over the majority of the non-spherical surface regions. The scale failure sections displayed a columnar structure, which is typical of $\mathrm{Y}$-containing alumina scales [9]. After 100 hours oxidation, $\alpha-\mathrm{Al}_{2} \mathrm{O}_{3}$ and $\mathrm{NiCO}_{2} \mathrm{O}_{4}$ were the major oxide phases on the un-coated specimens of Rene'N5.

\subsection{TBC Interfacial Reaction Products}

After 1 hour oxidation, SEM/EDS of a TBC-coated specimen indicated a continuous alumina scale (approximately $1.25 \mu \mathrm{m}$ thick) at the bond coat/YSZ interface. The scale contained Y-rich oxide particles which likely consisted of the $\mathrm{Y}_{2} \mathrm{O}_{3}$ detected by XRD of the bare NiCrAlY after 1 hour. Small elongated particles of a Y-rich metallic phase were detected in the NiCrAlY near the scale-metal interface. Yttrium-rich phases consisting of intermetallic yttrides such as $\mathrm{Ni}_{5} \mathrm{Y}$ (which dissolves at $1000^{\circ} \mathrm{C}$ ) have been reported in NiCoCrAlY [10].

After 100 and 200 hours oxidation, SEM of TBC cross-sections (Type C and D) indicated a continuous scale along the bond coat/top coat interface with no noticeable differences as a function 
of YSZ thickness. Minimal internal oxidation of the NiCrAlY occurred. The average thickness of the interfacial scales was $5.2 \mu \mathrm{m}$ after 100 hours and $6.4 \mu \mathrm{m}$ after 200 hours. Cracking in the scale cross-section was common near bond coat surface asperities, but in general the scales displayed good adherence with minimal scale/metal voids or delaminations.

A typical cross-section of the interfacial scale is shown in Fig. 3. A porous, lighter-contrast layer containing $\mathrm{Ni}, \mathrm{Al}, \mathrm{Cr}$, and $\mathrm{O}$ was intermittently present at the outer surface of the scale (in contact with the YSZ). This phase has been previously reported as $\mathrm{Ni}(\mathrm{Cr}, \mathrm{Al})_{2} \mathrm{O}_{4}[11]$, which was consistent with the XRD results of the oxidized bare NiCrAlY. The presence of the spinel layer (with thickness of $0-8.0 \mu \mathrm{m}$ ) did not degrade the adhesion of the YSZ during isothermal testing.

The dark-contrast, major phase in the interfacial scale of Fig. 3 was $\mathrm{Al}_{2} \mathrm{O}_{3}$. Within the continuous alumina scale there were lighter-contrast, Y-rich oxides present as either discrete particles, as reported previously [6], or as narrow bands oriented perpendicular to the surface and often originating at the scale/metal interface. The Y-rich oxides likely consisted of the YAG phase detected by XRD of the bare bond coatings.

Segregation of reactive-element ions such as yttrium to alumina scale grain boundaries is reported to increase inward diffusion of oxygen while decreasing the outward diffusion of aluminum, resulting in the promotion of an inward-growing columnar scale with improved adherence [11]. The presence of excess $Y(1.0 \mathrm{wt} . \%)$ in this alloy may have resulted in the formation of Y-rich intermetallic phases which dissolved at $1150^{\circ} \mathrm{C}$. This excess $\mathrm{Y}$ may have formed $\mathrm{Y}_{2} \mathrm{O}_{3}$ along the columnar $\mathrm{Al}_{2} \mathrm{O}_{3}$ grain boundaries during the initial stages of oxidation. Subsequent high-temperature reactions between the inter-columnar $\mathrm{Y}_{2} \mathrm{O}_{3}$ and the surrounding $\mathrm{Al}_{2} \mathrm{O}_{3}$ may have resulted in formation of the bands of YAG seen in Fig. 3. An alternate explanation involves the formation of Y-rich "pegs" (by reaction with Y-rich metallic phases) beneath the scale/metal interface during the early stages of oxidation. These "pegs" may have been gradually enveloped by the inward-growing scale to form the Y-rich bands seen in Fig. 3. Pegging was not apparent at the scale-metal interface after 100 or 200 hours oxidation, although such an effect might have been present at shorter time periods. 
The presence of continuous YAG stringers across the scale could compromise the protective nature of the scale by providing a path for rapid inward diffusion of oxygen, or by creating mechanical discontinuities that can act as stress risers. However, the presence of YAG did not degrade the adhesion of the scale or YSZ under the isothermal conditions of this study.

\subsection{Thermal Cycle Testing}

Thermally cycled specimens failed at 348 and 360 cycles, which compares favorably to the reported cyclic lifetimes of similar $\mathrm{TBC}$ systems at $1135^{\circ} \mathrm{C}$ [1]. Failures occurred by separation of the entire YSZ top coat as one monolithic piece. Failure occurred within the YSZ layer, and the majority of the bond coat surface was still covered with adherent YSZ after separation of the top coating. Evaluation of the bond coat side of the failure surface by XRD indicated zirconia as the major phase, with some $\mathrm{Al}_{2} \mathrm{O}_{3}$, spinels and trace amounts of YAG detected.

A NiCrAlY surface particle protruding through the YSZ which remained adhered to the bond coat surface is shown in Fig. 4(a). The separation of the top coat sheared the interfacial scale from the top half of the spherical particle, exposing the scale failure surface in cross section. A magnified view of the scale failure surface showing the underlying bare NiCrAlY and the remnants of several discrete layers of interfacial scale appears in Fig. $4(\mathrm{~b})$. The thick $(4.7 \mu \mathrm{m})$ outermost layer of scale was the original scale, and consisted of $\mathrm{Al}_{2} \mathrm{O}_{3}$ with some $\mathrm{Ni}$ and $\mathrm{Cr}$ (spinels) in its outermost surface. There were 1 to 3 additional scale layers underlying the outer layer. The interior scales were significantly thinner $\left(1.4\right.$ to $3.0 \mu \mathrm{m}$ ), and consisted mainly of $\mathrm{Al}_{2} \mathrm{O}_{3}$ (with traces of $\mathrm{Cr}$ detected). The inner layers formed and detached during subsequent cycles after localized separation of the original scale had occurred.

During the cooling cycles, compressive thermal expansion mismatch stresses in the YSZ and the alumina scale (enhanced by the relatively sharp radius of the spherical particle) may have contributed to localized scale buckling with delamination occurring along the peaks of the bond coat asperity. The overall scale remained adherent due to the constraint of the overlying strain-tolerant YSZ layer. Other studies have reported that fractures commonly occur within the YSZ near the 
plane of the bond coat peaks for thermally cycled plasma-sprayed TBCs [3]. It is possible that along the bond coat peaks, out-of-plane tensile stresses caused by scale wedging (due to the growth and fracture of additional scale layers under the YSZ) may be a factor which contributes to top coat separation.

\section{Conclusions}

1. The formation and growth of spinels and YAG within the interfacial reaction products of a plasma-sprayed TBC did not degrade the adhesion of the YSZ during accelerated isothermal testing $\left(1150^{\circ} \mathrm{C}\right)$ for up to 200 hours.

2. Failure of the plasma-sprayed YSZ under thermal cycling conditions occurred within the ceramic layer. The plane of separation was coincident with the bond coat peaks.

3. The presence of multi-layered alumina scales on the failure surfaces of the bond coat peaks indicates localized separation and reformation of the interfacial scale underneath the YSZ during thermal cycling. Growth of the layered subscales at bond coat peaks may be a contributing mechanism to failure of plasma-sprayed TBCs.

\section{Acknowledgments}

The authors gratefully acknowledge Dr. B. Nagaraj of G.E. Aircraft Engines, Cincinnati, OH for providing technical advice and substrate material. Coatings were plasma sprayed by G. Bancke and Prof. C. Berndt of the Thermal Spray Laboratory at State University of New York, Stony Brook. Research was sponsored by the Assistant Secretary for Energy Efficiency and Renewable Energy, Office of Transportation Technologies, as part of the High Temperature Materials Laboratory Fellowship Program, Oak Ridge National Laboratory, managed by Lockheed Martin Energy Research Corp. for the U.S. Department of Energy under contract number DE-AC0596 OR22464. 


\section{References}

1. D.J. Wortman, B.A. Nagaraj, and E.C. Duderstadt, Mater. Sci. Eng., A121 (1989) 433-440.

2. R.V. Hillery, B.H. Pilsner, R.L. McKnight, T.S. Cook, and M.S. Hartle, NASA CR180807(1988).

3. J.T. DeMasi, K.D. Sheffler, M. Ortiz, NASA CR 182230, (1989).

4. B.C. Wu, E. Chang, D. Tu. and S. L. Wang, Mat. Sci. and Eng., A, 111 (1989) 201.

5. R.A. Miller, J. Eng. Gas Turbines Power, 111 (1989) 301-305.

6. W.J. Brindley and R.A. Miller, Surf. Coat. Tech., 43/44, (1990) 446-457.

7. A.S. Kahn, C.E. Lowell, and C.A. Barrett, Journal Electrochem. Soc., 127 (3) (1980) 670 679.

8. M.M. Mora, R.R. Biederman and R.D. Sisson, Jr., Thin Solid Films, 119 (1984) 383-394.

9. B.A. Pint, Oxid. Metals, 45 (1996) 1 - 37.9.

10. S. Sacre, U. Weinstroth, H.G. Feller, and L.K. Thomas, J. Mater. Sci., 28 (1993) 18431848.

11. L. Lelait, S. Alperine and R. Mevrel, J. Mater. Sci., 27 (1992) 5 - 12 
Table I. Rene'N5 Nominal Composition (wt.\%)

\begin{tabular}{lllllllllllll}
\hline & Ni & Co & Cr & Ta & Al & W & Re & Mo & Y & Hf & C \\
\hline Rene N5 & Bal & 7.5 & 7.0 & 6.5 & 6.2 & 5.0 & 3.0 & 1.5 & $<0.5$ & 0.15 & 0.05 \\
\hline
\end{tabular}

Less than 3 ppm S 
Table II. Plasma-spray Parameters

\begin{tabular}{ccccccccc}
\hline Powders & Process & $\begin{array}{c}\text { Amperage } \\
\text { (A) }\end{array}$ & $\begin{array}{c}\text { Voltage } \\
\text { (V) }\end{array}$ & $\begin{array}{c}\text { Ar Flow } \\
\text { (SLM) }\end{array}$ & $\begin{array}{c}\mathrm{H}_{2} \text { Flow } \\
(\mathbf{S L M})\end{array}$ & $\begin{array}{c}\text { Distance } \\
(\mathbf{c m})\end{array}$ & $\begin{array}{c}\text { Flow }^{+} \\
(\mathbf{g} / \mathbf{m i n})\end{array}$ & $\begin{array}{c}\text { Traverse } \\
(\mathbf{c m} / \mathbf{s e c})\end{array}$ \\
\hline NI-343 & VPS* & 650 & 68 & 50 & 8.5 & 30 & 39 & 3 \\
NI-211 & VPS* & 650 & 68 & 50 & 8.5 & 30 & 27 & 3 \\
$204 \mathrm{NS}$ & APS & 500 & 71 & 35 & 10 & 12 & 31 & 3 \\
\hline
\end{tabular}

SLM $=$ standard liters $\mathrm{min}^{-1}{ }^{*}$ Chamber pressure $30 \mathrm{mbar} .{ }^{+}$Powder flow rate.

VPS specimens reached a temperature of approximately $900^{\circ} \mathrm{C}$ during spraying.

Specimens were air-cooled during APS with substrate temperatures not exceeding $250^{\circ} \mathrm{C}$. 
Table III. TGA Specimen Descriptions

\begin{tabular}{cccccc}
\hline $\begin{array}{c}\text { Specimen } \\
\text { Type }\end{array}$ & Bond & Top & Surface & Surface & Surface \\
\hline Coating & Coating & Condition & $\mathbf{R}_{\mathbf{A}}(\mu \mathbf{m})^{*}$ & $\mathbf{R}_{\mathbf{Q}}(\mu \mathbf{m})^{*}$ \\
B & none & none & as-machined & 0.84 & 1.08 \\
C & $150 \mu \mathrm{m} \mathrm{NiCrAlY}$ & none & both faces coated & 14.2 & 18.5 \\
D & $150 \mu \mathrm{m} \mathrm{NiCrAlY}$ & $250 \mu \mathrm{m} \mathrm{YSZ}$ & both faces coated & NA & NA \\
\hline
\end{tabular}

* $\mathrm{R}_{\mathrm{A}}$ is the arithmetical mean deviation of the areas of all roughness profile values, and $\mathrm{R}_{\mathrm{Q}}$ is the root-mean-square calculation of all roughness profile values.

\section{DISCLAIMER}

This report was prepared as an account of work sponsored by an agency of the United States Government. Neither the United States Government nor any agency thereof, nor any of their employees, makes any warranty, express or implied, or assumes any legal liability or responsibility for the accuracy, completeness, or usefulness of any information, apparatus, product, or process disclosed, or represents that its use would not infringe privately owned rights. Reference herein to any specific commercial product, process, or service by trade name, trademark, manufacturer, or otherwise does not necessarily constitute or imply its endorsement, recommendation, or favoring by the United States Government or any agency thereof. The views and opinions of authors expressed herein do not necessarily state or reflect those of the United States Government or any agency thereof. 
Table IV. Results of Thermogravimetric Analysis $\left(1150^{\circ} \mathrm{C}\right)$

\begin{tabular}{|c|c|c|c|c|c|c|}
\hline $\begin{array}{l}\text { Specimen } \\
\text { Number }\end{array}$ & $\begin{array}{l}\text { Coating } \\
\text { Type }\end{array}$ & $\begin{array}{r}\text { Time } \\
- \\
\text { (hrs) }\end{array}$ & $\begin{array}{c}\text { Initial } \\
\text { Mass (g) }\end{array}$ & $\begin{array}{c}\text { Total } \\
\Delta \text { Mass (g) }\end{array}$ & $\begin{array}{c}k_{p}^{*} \\
\left(g^{2} \mathrm{~cm}^{-4} s^{-1}\right)\end{array}$ & $\begin{array}{c}R^{2} \text { Values } \\
\left(k_{p}^{1 / 2} \text { fit }\right)\end{array}$ \\
\hline A2 & none & 100 & 10.5672 & 0.0030 & $9.11 \times 10^{-13}$ & 0.987 \\
\hline A3 & none & 100 & 10.5637 & 0.0026 & $8.08 \times 10^{-13}$ & 0.995 \\
\hline B1 & bare NiCrAlY & 100 & 11.2068 & 0.0241 & $1.45 \times 10^{-12}$ & 0.992 \\
\hline $\mathrm{B} 2$ & bare $\mathrm{NiCrAlY}$ & 200 & 11.3041 & 0.0271 & $9.17 \times 10^{-13}$ & 0.981 \\
\hline B3 & bare $\mathrm{NiCrAlY}$ & 50 & 11.2534 & 0.0219 & $2.15 \times 10^{-12}$ & 0.990 \\
\hline B4 & bare $\mathrm{NiCrAlY}{ }^{+}$ & 100 & 10.6283 & 0.0086 & $1.51 \times 10^{-12}$ & 0.999 \\
\hline $\mathrm{Cl}$ & $250 \mu \mathrm{m}$ TBC & 100 & 12.2577 & 0.0260 & $1.49 \times 10^{-12}$ & 0.985 \\
\hline $\mathrm{C} 2$ & $250 \mu \mathrm{m}$ TBC & 200 & 12.4270 & 0.0296 & $1.04 \times 10^{-12}$ & 0.986 \\
\hline $\mathrm{C} 3$ & $250 \mu \mathrm{m} \mathrm{TBC}$ & 50 & 12.3219 & 0.02161 & $1.77 \times 10^{-12}$ & 0.986 \\
\hline D1 & $500 \mu \mathrm{m} \mathrm{TBC}$ & 100 & 13.4996 & 0.0271 & $1.54 \times 10^{-12}$ & 0.986 \\
\hline $\mathrm{D} 2$ & $500 \mu \mathrm{m} \mathrm{TBC}$ & 200 & 13.4169 & 0.0278 & $8.97 \times 10^{-13}$ & 0.984 \\
\hline D3 & $500 \mu \mathrm{m}$ TBC & 50 & 13.3741 & 0.0226 & $1.13 \times 10^{-12}$ & 0.999 \\
\hline
\end{tabular}

${ }^{+}$All surfaces of specimen B-4 were polished to $3 \mu \mathrm{m}$ alumina.

* $k_{p}{ }^{1 / 2}$ was determined by a linear regression fit of the slope of the steady-state region of each corrected parabolic curve. 


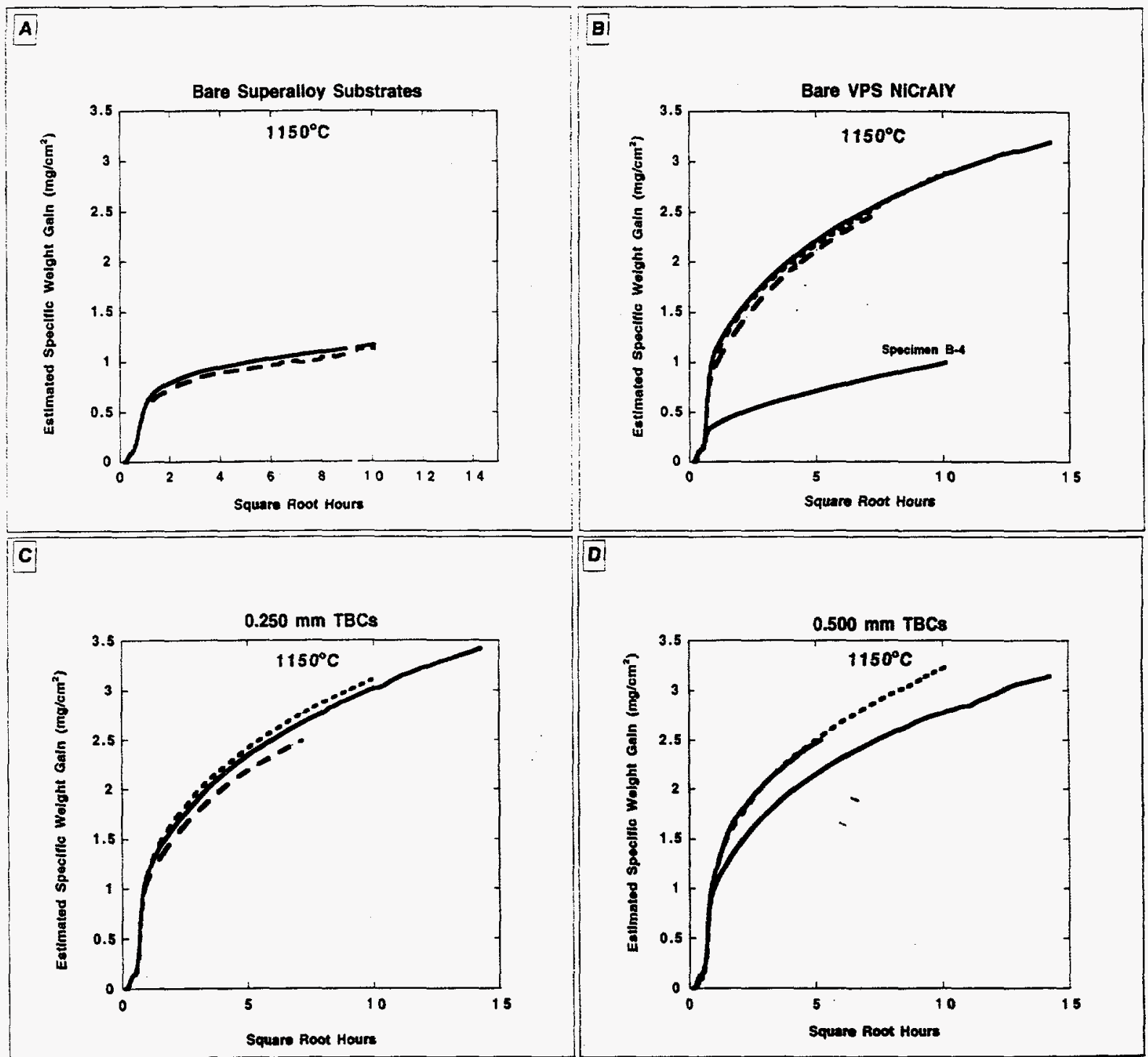

Fig. 1. Parabolic plots of the isothermal oxidation weight gains at $1150^{\circ} \mathrm{C}$ in dry air for (a) bare Rene'N5 (with as-machined surfaces), (b) bare VPS NiCrAIY, (c) $250 \mu \mathrm{m}$ TBCs, and:(d) $500 \mu \mathrm{m}$ TBCs. The surface area of a flat substrate was used to calculate all specific weight gains. 

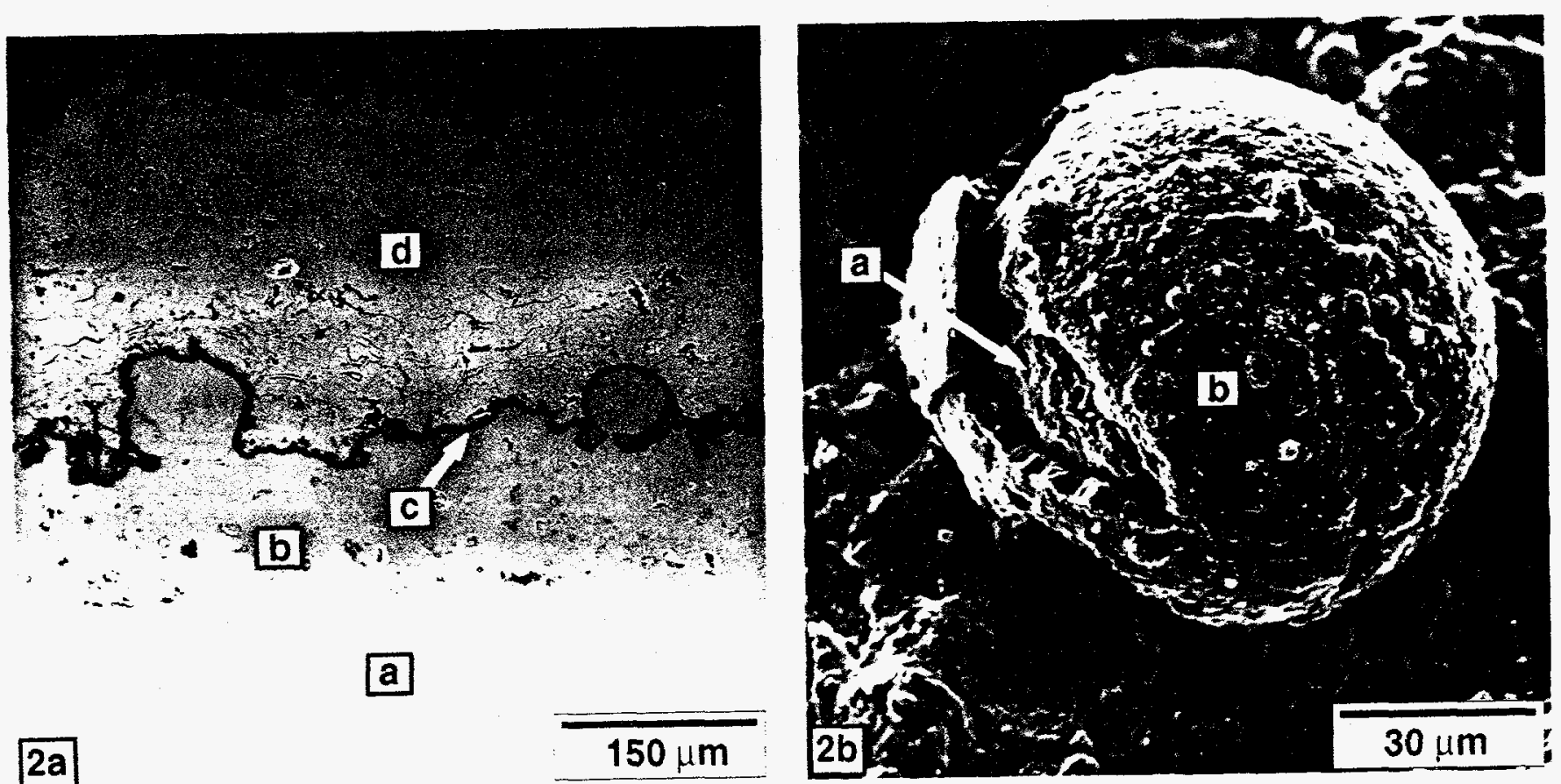

Fig. 2. Secondary electron images of: (a) Type C TBC cross-section after 200 hours oxidation showing the (a) substrate, (b) bond coat, (c) interfacial scale, (d) YSZ. Note the bond coat interface roughness and the spherical surface particles interlocked with the YSZ. (b) Spherical particle on a bare NiCrAlY surface after 100 hours isothermal oxidation showing (a) bare NiCrAlY, and (b) scale which has cracked and partially spalled. 


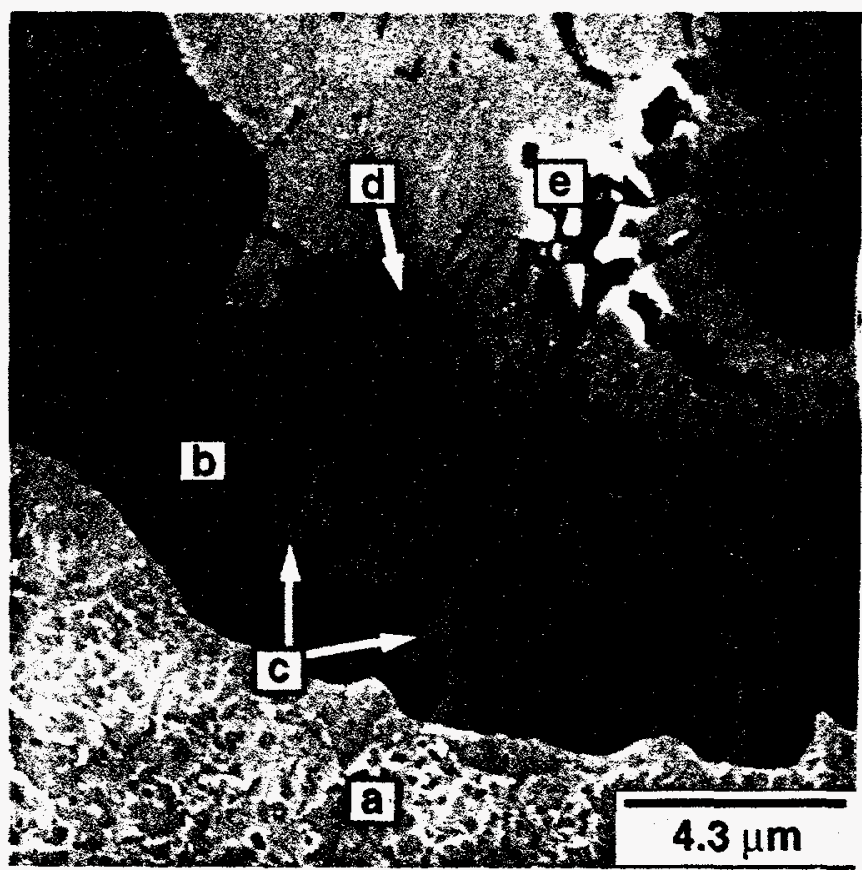

Fig. 3. Secondary electron micrograph of the bond coat/top coat interface of a Type-C TBC specimen after 200 hours at $1150^{\circ} \mathrm{C}$. The features labeled are: (a) bond coating, (b) $\mathrm{Al}_{2} \mathrm{O}_{3}$ scale, (c) alumina-yttria particles, (d) $\mathrm{Ni}(\mathrm{Cr}, \mathrm{Al})_{2} \mathrm{O}_{4}$ spinels, and (e) YSZ top coating. 

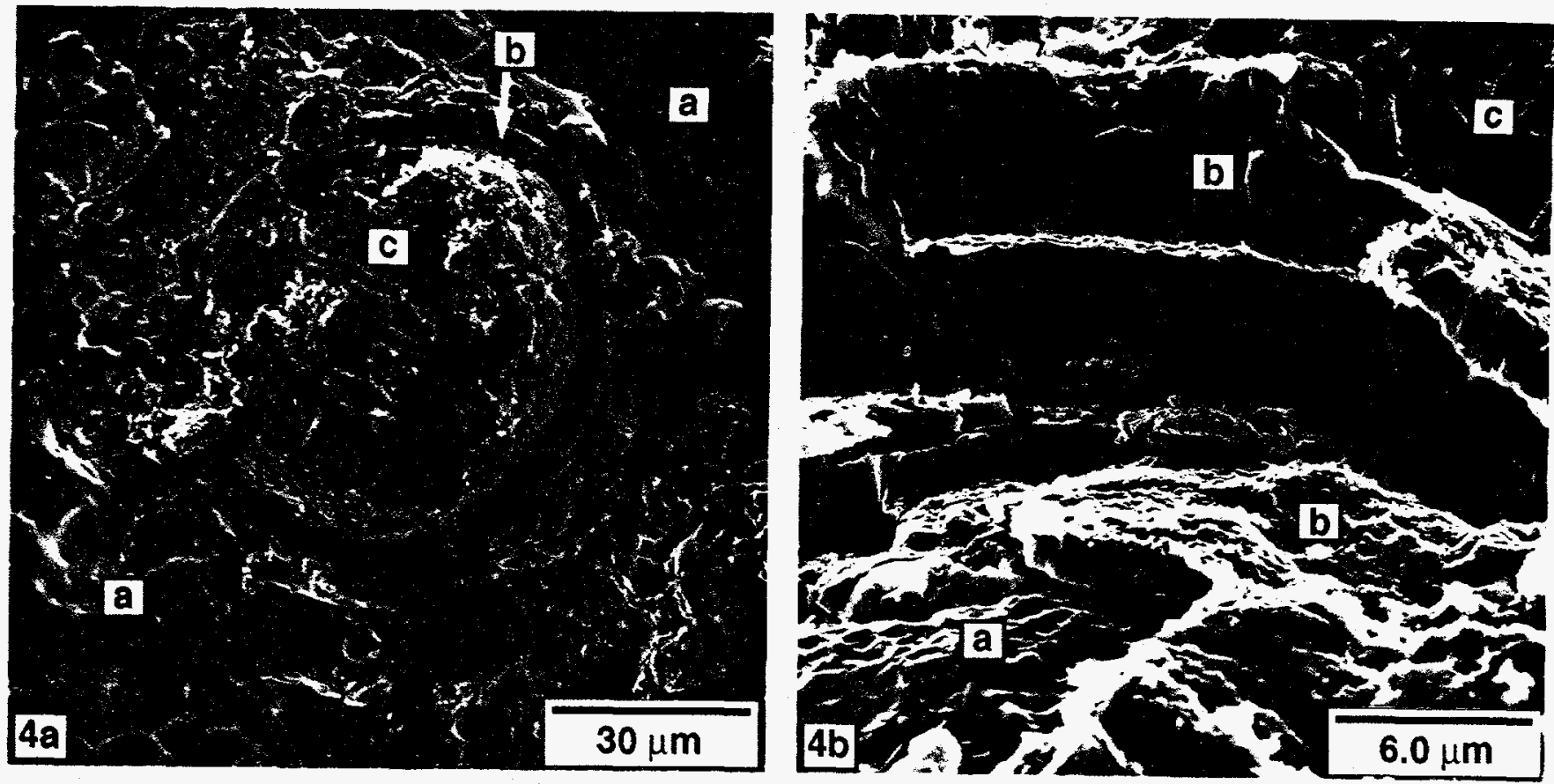

Fig. 4. (a) Secondary electron images of the substrate side of the YSZ failure surface after thermal cycling, showing: (a) YSZ remaining adhered to the majority of the bond coat surface, (b) cross-sectional fracture surface of the interfacial scale, and (c) protruding NiCrAlY surface particle covered by a cracked subscale.

(b) Scale failure surface on a spherical particle showing (a) bare NiCrAIY, (b) various layers of alumina scales, and (c) surrounding YSZ 